\title{
Fish as Potential Controllers of Invasive Mollusks in a Neotropical Reservoir
}

\author{
Camila Ribeiro Coutinho de Oliveira ${ }^{1}$, Rosemara Fugi ${ }^{2}$, \\ Kelly Patrícia Brancalhão² \& Angelo Antonio Agostinho ${ }^{2, *}$
}

${ }^{1}$ Limnobios Consultoria em Ambientes Aquáticos, Maringá, PR, Brazil

${ }^{2}$ Universidade Estadual de Maringá - Nupelia/DBI/PEA, Maringá, PR, Brazil

\begin{abstract}
We evaluated the importance of the invasive mollusks (Corbicula fluminea and Limnoperna fortunel) in the diets of the fish species through analysis of stomach contents of fish caught in the commercial fishery in the years 2005 and 2006 in the Itaipu Reservoir (Upper Paraná River). The degree that these bivalves are processed in the digestive tract was used to identify potential controllers. Food items were evaluated by using the methods of occurrence, volume, and Feeding Index (IAi). Out of the 36 fish species present in the fishery landings, 24 consumed $L$. fortunei and 12 consumed $C$. fluminea. In order to evaluate the possibility that the bivalves pass through the digestive tract of the predator without any damage, their degree of digestion was evaluated. Only species with morphological pre-adaptations for a malacophagous diet, or that managed to crush the shells of these bivalves were very successful with this kind of food. In particular, Megalancistrus parananus, Leporinus obtusidens, and Leporinus macrocephalus may be regarded as potential biological control agents for these invasive populations.
\end{abstract}

Key words: Introduced Species, Biological Control, Golden Mussel, Corbicula, Limnoperna.

\section{Introduction}

The introduction of species is widely recognized as a serious problem that involves huge economic losses and constitutes one of the most important global threats to biodiversity and ecosystem functioning (Pimentel et al. 2000). Currently, a large number of organisms are released outside their native range, a process that involves multiple taxonomic groups and many types of environments in different parts of the world (Vitousek et al. 1997). Given the current ease of transport, innumerable introductions can take place within a short space of time.

The impacts on native wildlife resulting from the proliferation of an introduced species can be categorized as: i) competition for resources, ii) exacerbation of predation, iii) changes in the habitat and functioning of the system, iv) introduction of pathogens and parasites, and v) genetic changes (Agostinho et al. 2006). An important aggravating factor is that other environmental disturbances often occur in conjunction with introductions (reservoir construction, fishing, pollution, habitat alterations), increasing the chances of colonization

${ }^{\star}$ Send correspondence to: Angelo Antonio Agostinho Universidade Estadual de Maringá - Nupelia/DBI/PEA, Av. Colombo, 5790, CEP 87020-900, Maringá, PR, Brazil E-mail: agostinhoaa@gmail.com of the invader and intensifying its negative effects, including causing extinctions (Gurevitch \& Padilha 2004).

Two recent cases of species introduced into inland waters of Brazil have drawn the attention of biologists, engineers, and economists. This is the arrival and dispersal of two species of Asian bivalves, the Asian clam Corbicula fluminea and the golden mussel Limnoperna fortunei (Darrigran 2002). These species were introduced into the mouth of the La Plata River basin through the release of ballast water from ships arriving from Southeast Asia. The first record of C. fluminea in South America occurred in the late 1960s (Ituarte 1981), and of L. fortunei in the early 1990s (Darrigran \& Pastorino 1993).

Since the 1990s, C. fluminea has been found in the floodplain of the Upper Paraná River (Takeda et al. 2004), and in 1994 a population boom of this species occurred throughout the length of the Itaipu Reservoir (Okada 2001). The first record of L. fortunei in this reservoir was in August 2001, and it was found in the floodplain located upstream of this reservoir in December 2002 (Takeda et al. 2004). Since then, these species have been causing negative effects on the native fauna, dam operations, and water-supply uptake (Takeda et al. 2007; Suriani et al. 2007). 
Fish have been reported to consume these mollusks, particularly the Doradidae Pterodoras granulosus, whose diet contains large amounts of C. fluminae and L. fortunei (Ferriz et al. 2000; Gaspar da Luz et al. 2002; Cantanhêde et al. 2008). Although the eradication of aquatic invasive species is a difficult task (Vitule et al. 2009), it is expected that intensive consumption can have an important role in their control. In this case, however, it is necessary to gain a comprehensive understanding of ecosystem processes and elements that operate in the reduction of the invasive populations. In this context, the main objective of the present study was to evaluate the components of the fish fauna that may have the conditions to control these invasive mollusks in Itaipu Reservoir, through analysis of stomach contents during two annual periods. Specifically we sought to determine the importance of the invasive mollusks in the diets of the fish species, and the degree that these bivalves are processed in the fish digestive tract.

\section{Materials and Methods}

Fish were obtained from the landings of the commercial fishery in Itaipu Reservoir (Upper Paraná River), during the years 2005 and 2006. All fishes sampled were measured and weighed, and stomachs and intestines containing food were fixed in $4 \%$ formalin. The gastro-intestinal contents of 3,752 specimens were analyzed (Table 1), and the food items were identified under optical and stereoscope microscope. The analyses were performed by using the methods of frequency of occurrence (FO) and volumetric frequency (FV) (Hyslop 1980). The importance of food items was inferred from the combination of these methods in the Feeding Index (IAi) (Kawakami \& Vazzoler 1980).
The IAi values were ordered from highest to lowest, and cumulative summations were made based on which were classified as preferred - up to 50\%; secondary - between 50 and 75\%; and accessory - all remaining items (Rosecchi \& Nouaze 1987).

For species in which the invasive bivalves were prominent in the diet, the degree of digestion (DD) of mollusks found in the stomach and intestine was evaluated according to the degree of integrity, using the following scale: $0=$ intact, $1=$ almost intact, 2 = valves fragmented and $3=$ muscle digested.

\section{Results}

\section{Diet composition}

The general analysis of the diet of 36 fish species sampled during 2005 (31 species) and 2006 (32) revealed the presence of 53 food items. These were grouped into nine categories, namely algae, basidiomycetes, crustaceans, detritus/sediment, insects, mollusks, other invertebrates, fish, and higher plants.

Taking as a criterion the occurrence and the values of the Feeding Index for the different categories of food items analyzed in 2005 and 2006, we noticed that algae, higher plants, detritus/sediment, mollusks, and insects occurred widely among the fish species. These were taken by at least $65 \%$ of the 31 species analyzed in 2005 , and $71 \%$ of the 32 in 2006 (Table 2). Mollusks were recorded in the stomach of 71 and $84 \%$ of the species in 2005 and 2006, respectively. However, mollusks proved to be dominant items for only 13 and $15 \%$ of the species during these years, respectively.

Table 1. Number of stomach contents analyzed $(\mathrm{N})$, and standard length range $(\mathrm{cm})(\mathrm{SL})$.

\begin{tabular}{lrrlrr}
\hline \multicolumn{1}{c}{ Species } & N & SL & Species & N & SL \\
\hline A. osteomystax & 118 & $17.1-28.6$ & M. lippincottianus & 210 & $8.2-34.2$ \\
A. ucayalensis & 5 & $18.7-23.6$ & P. anisitsi & 33 & $19.3-43.4$ \\
C. jenynsii & 6 & $15.4-17.4$ & P. galeatus & 195 & $11.8-19.5$ \\
C. kelberi & 32 & $19.3-35.2$ & P. granulosus & 1368 & $16.3-57.3$ \\
H. commersoni & 26 & $19.9-33.7$ & P. maculatus & 95 & $9.0-32.5$ \\
H. regani & 18 & $20.3-32.8$ & P. mesopotamicus & 31 & $12.4-38.0$ \\
H. ternetzi & 90 & $16.5-30.5$ & P. squamosissimus & 480 & $12.5-55.9$ \\
H. aurogutatus & 6 & $16.5-25.3$ & P. lineatus & 30 & $15.6-43.2$ \\
H. malabaricus & 48 & $16.2-34.7$ & P. motoro & 30 & $22.5-33.7$ \\
Hypostomus sp. & 10 & $13.3-28.8$ & P. ornatus & 7 & $18.9-32.6$ \\
I. labrosus & 101 & $14.7-26.3$ & P. pirinampu & 57 & $20.3-55.3$ \\
L. friderici & 34 & $18.0-28.5$ & R. aspera & 43 & $15.4-40.5$ \\
L. macrocephalus & 17 & $21.0-53.0$ & R.. vulpinus & 39 & $20.8-52.7$ \\
L. obtusidens & 11 & $19.5-25.8$ & S. borellii & 75 & $15.5-31.5$ \\
L.lacustris & 5 & $15.1-21.4$ & S. marginatus & 60 & $11.7-38.0$ \\
Loricaria sp. & 23 & $13.8-43.6$ & S. pappaterra & 211 & $9.2-20.5$ \\
L. platymetopon & 11 & $21.5-28.7$ & S. nasutus & 6 & $18.4-31.2$ \\
M. parananus & 165 & $18.0-44.7$ & S. maculatus & 56 & $10.3-24.6$ \\
\hline
\end{tabular}


Table 2. Number of species in which different food categories were recorded (Occur) and in which they were preferred (Preferred).

\begin{tabular}{lcccccc}
\hline \multirow{2}{*}{ Item } & \multicolumn{2}{c}{2005} & & \multicolumn{2}{c}{2006} \\
\cline { 2 - 3 } \cline { 5 - 6 } \cline { 5 - 6 } Algae & Occur & Preferred & & Occur & Preferred \\
Basidiomycetes & 26 & 5 & & 27 & 4 \\
Crustaceans & 13 & - & & - & - \\
Detritus/sediment & 23 & 1 & & 27 & 10 \\
Insects & 21 & 3 & & 23 & 3 \\
Mollusks & 22 & 4 & & 27 & 5 \\
Other invertebrates & 15 & - & & 16 & - \\
Fish & 16 & 8 & & 16 & 7 \\
Higher plants & 25 & 2 & & 25 & 2 \\
\hline Total species & & 31 & & & 32 \\
\hline
\end{tabular}

\section{Diets of the potential control species for invasive mollusks}

Among the fish that consumed mollusks, 24 species ate $L$. fortunei and 12 ate $C$. fluminea. However, the importance of these items in the diet showed high interspecific and interannual variation.

Limnoperna fortunei was recorded in the digestive tract of 15 out of the 31 fish species analyzed in 2005, and in 24 of 32 examined in 2006 (Figure 1). However, this item was prominent in the diet of only 6 species analyzed in 2005, i.e., Megalancistrus parananus (84\%), Leporinus macrocephalus (79\%), Pterodoras granulosus (47\%), Hypostomus ternetzi (37\%), Serrasalmus marginatus (17\%), and Piaractus mesopotamicus (15\%). In 2006, although more species used this invasive bivalve in their diet, in only three of them the golden mussel reached meaningful proportions: $M$. parananus (82\%), Leporinus obtusidens (60\%), and P. granulosus (29\%).

The clam C. fluminea was present in the diet of 10 species in 2005, and of 9 species in 2006. Notably, however, this clam did not comprise more than $10 \%$ of the diet of any of them (Figure 1).

\section{Degree of digestion of the bivalves}

Of the seven species that consumed meaningful amounts of L. fortunei, L. obtusidens, L. macrocephalus and M. parananus consumed the highest percentages of this mollusk, and with the maximum degree of digestion $(83,80$ and $44 \%$, respectively) (Figure 2). Approximately $70 \%$ of the digestive tracts of $L$. obtusidens and M. parananus contained mussels showing evidence of at least the beginning of digestion. For L. macrocephalus this percentage was $100 \%$. In the digestive tract of $P$. mesopotamicus, about half of the mussels were moderately digested (Degree of Digestion $=2$ ). The highest incidences of intact mussels $(\mathrm{DD}=0)$ were observed for P. granulosus (78\%) and S. marginatus (89\%) (Figure 2).

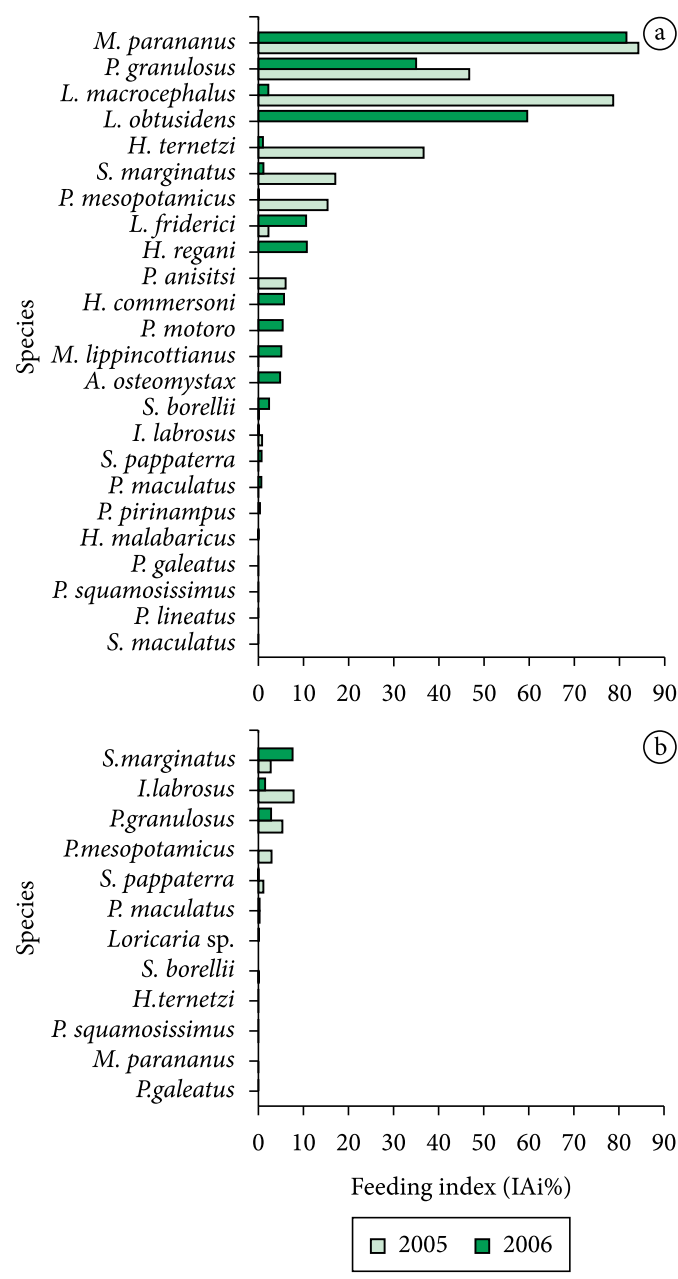

Figure 1. Importance of the invasive golden mussel Limnoperna fortunei (a) and Asian clam Corbicula fluminea (b) in the diet of fish species from the commercial fishery landings in Itaipu Reservoir, during the years 2005 and 2006.

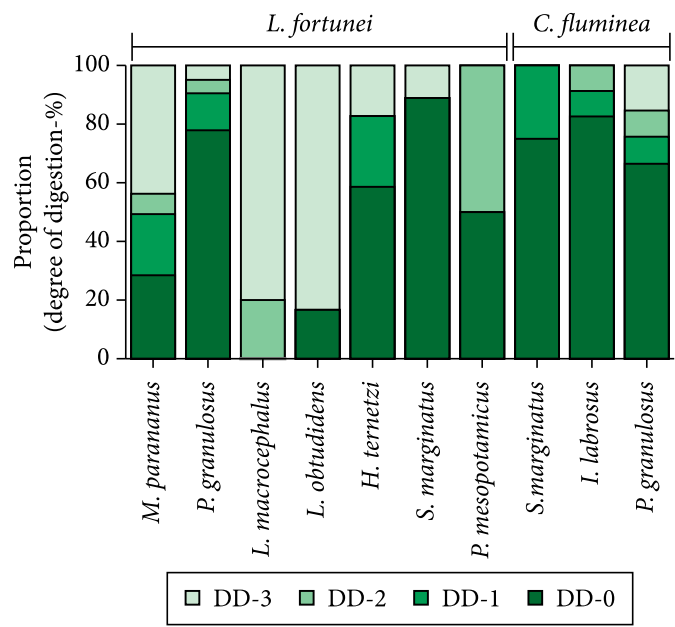

Figure 2. Percentage of occurrence of the invasive bivalves Limnoperna fortunei and Corbicula fluminea in different degrees of digestion (DD; DD-0, intact; DD-1, almost intact; DD-2, valves fragmented; DD-3, muscle digested) in the digestive tract of malacophagous fish species in the Itaipu Reservoir. 
Regarding the proportion of clams C. fluminea that were digested to some degree by the three species that consumed meaningful amounts of it, S. marginatus and I. labrosus were inefficient in digesting clams, and for P. granulosus, although the majority of shellfish found in the gut were not digested $(\mathrm{DD}=0)$, a percentage of this item was found in advanced stages of digestion (Figure 2).

\section{Discussion}

The ingestion of mollusks by about $2 / 3$ of the species examined can be explained by the massive proliferation of the invading bivalves C. fluminea and L. fortunei in the Itaipu Reservoir, as reported by Takeda et al. (2004, 2007). These invasive bivalves were found in the diet of several fish species, and comprised a significant share of the gastric contents of some of them. The presence of these bivalves attests to the high feeding plasticity, and especially the trophic opportunism of the fish, which exploited an unusual resource, invasive species that have recently become established locally, but are now easily available.

Of the two invasive species, L. fortunei was the more preyed upon, and was recorded in more than $65 \%$ of the species analyzed. This indicates that this mussel may be more available than the clam C. fluminea. Unlike the latter, L. fortunei colonizes hard substrates, and the lack of competitors for this type of substrate in the Itaipu Reservoir may have led to increased density of this mollusk (Takeda et al. 2002). The shell of $L$. fortunei is more fragile than that of C. fluminae, and it is easier to break and to access its tissues (Cantanhêde et al. 2008), which may also account for the fishes preference for the mussels.

Different groups of fish incorporated the invasive mollusk into their diet, especially species with omnivorous or detritivorous habits (Garcia \& Montalto 2006). However, ingestion of these organisms does not necessarily imply a successful strategy for the predator, as evidenced by the high incidence of intact (undigested) prey in the digestive tract. The presence of intact mollusks in several fish species suggests that the mollusks cannot be digested and probably pass through the fish alive. In this case, these fish species may, rather than controlling these invasive organisms, instead contribute to their dispersal. This possibility was suggested for P. granulosus by Cantanhêde et al. (2008), who recorded a large number of closed shells of $C$. fluminae present in the end of the intestine of this species.

Only species with morphological preadaptations for a malacophagous diet, or that can break the valves of these bivalves, are very successful with this type of food and can be considered predators. Garcia \& Montalto (2006) noticed that fish that predate these exotic mollusks generally have mouths adapted for suction or are provided with strong incisiform or molariform teeth, and may have pharyngeal teeth with different degrees of development.
In this study, M. parananus, Leporinus obtusidens and L. macrocephalus showed to be important mollusk predators. Among the species considered here as malacophagous, $M$. parananus seems to act most effectively in the control of L. fortunei because it crushes the mussel. Characterized as a detritivore, this species has a ventral mouth equipped with strong maxillar and pharyngeal teeth compared to other species of loricariids (Delariva \& Agostinho 2001).

Leporinus obtusidens, an omnivorous species, profoundly altered its diet in the Middle Paraná River after the arrival of L. fortunei (Garcia \& Montalto 2006). This species possesses a small terminal mouth provided with large strong incisiform oral teeth, in addition to pharyngeal teeth. The small mouth opening means that ingested organisms must be small in size, or be fragmented by the oral teeth. The conformation of their premaxillary and mandibular teeth affords a wide grinding surface that allows the fragmentation of hard organisms (Occhi \& Oliveros 1974), which explains the presence of broken bivalve shells in their stomach contents.

Leporinus macrocephalus, a species previously absent from the Upper Paraná River, has, like L. obtusidens, a terminal mouth, a small oral cleft, and a relatively large buccopharyngeal cavity, with incisiform oral teeth and hooked pharyngeal teeth, responsible for the holding and maceration of the prey (Rodrigues et al. 2006).

The catfish P. granulosus is the species most often taken in the commercial fishery in Itaipu Reservoir (Okada et al. 2005). Its consumption of L. fortunei and C. fluminae has been documented for the Paraná River basin (Ferriz et al. 2000; Gaspar da Luz et al. 2002; Cantanhêde et al. 2008). The pharyngeal teeth, arranged in plates, are small, and the species' diet has been described as omnivorous, opportunistically taking the most available food (Gaspar da Luz et al. 2002). In contrast to the observations for Leporinus spp. and M. parananus, P. granulosus ingests the whole bivalves, and although it can digest a portion of them, the integrity of many individuals present in the digestive tract suggests that this great migrator can contribute to the dispersal of these invaders, especially C. fluminea.

In summary, our findings show that these bivalve invaders are widely consumed by the components of the ichthyofauna of the Itaipu Reservoir, as a result of the feeding plasticity of the fish and the high availability of this new food resource in the basin. The effectiveness of the fish species in using this resource and the role of this group of animals in the control of these invaders depends, however, on the degree of pre-adaptation of the species to a malacophagous diet. In discussions about the role of fish in the biological control of invasive species of bivalves, there is a consensus that, even though the fish cannot exterminate them, they contribute to maintaining their populations at lower levels of density (Garcia \& Montalto 2006; Cantanhêde et al. 2008). However, this contribution is naturally species-specific, and experimental investigations on the possible disperser capacity of some of the fish species are needed to clarify this role. 


\section{Acknowledgements}

The authors are grateful to the Núcleo de Pesquisas em Limnologia, Ictiologia e Aquiicultura of the Universidade Estadual de Maringá, in the persons of Edson K. Okada and Maria de Lourdes B. Nunes who kindly provided the biological material for the development of this study. Thanks are also due to $\mathrm{CNPq}$ for a scientific initiation grant to Camila R. C. Oliveira, and a researcher grant to Angelo A. Agostinho.

\section{References}

Agostinho AA, Pelecice FM \& Júlio Jr HF, 2006. Biodiversidade e Introdução de Espécies de Peixes: unidades de conservação. In: Campos JB, Tossulino MGP \& Muller CRC (Ed.). Unidades de Conservação: ações para valorização da biodiversidade. Curitiba: Instituto Ambiental da Paraná. p. 95-117.

Cantanhêde G et al., 2008. Invasive molluscs in the diet of Pterodoras granulosus (Valenciennes, 1821) (Pisces, Doradidae) in the Upper Paraná River floodplain, Brazil. Ecology of Freshwater Fish, 17:47-53.

Darrigran G \& Pastorino G, 1993. Bivalvos invasores en el Rio de la Plata, Argentina. Comunicaciones de la Sociedad Malacologica del Uruguay, 7:309-313.

Darrigran G, 2002. Potencial impact of filter-feeding invaders on temperate inland freshwalter environments. Biological Invasions, 4:145-156.

Delariva RL \& Agostinho AA, 2001. Relationship between morphology and diets of six neotropical loricariids. Journal of Fish Biology, 58:832-847.

Ferriz RA et al., 2000. Alimentacion del Pterodoras granulosus (Valenciennes), (Pisces, Doradidae) em la baja cuenca del Plata. Revista del Museo Argentino de Ciências Naturales, 2:151-156.

Garcia M \& Montalto L, 2006. Los peces depredadores de Limnoperna fortunei en los ambientes colonizados. In: Darrigran G and Damborenea C (Ed.). Bio-invasion del mejillón dorado en el continente americano. La Plata: Edulp. p. 111-127.

Gaspar da Luz KD et al., 2002. Alterations in the Pterodoras granulosus (Valenciennes, 1833) (Osteichthyes, Doradidae) diet due to the abundance variation of a bivalve invader species in the Itaipu Reservoir, Brazil. Acta Scientiarum, 24:427-432.

Gurevitch J \& Padilha DK, 2004. Are invasive species a major cause of extinctions? Trends in Ecology and Evolution, 19:470-474.

Hyslop EJ, 1980. Stomach contents analysis review of methods and their applications. Journal of Fish Biology, 17:411-429.

Ituarte CF, 1981. Primera noticia acerca de la presencia de pelecípodos asiáticos en el área rioplatense. Neotropica, 27:79-82.
Kawakami E \& Vazzoler G, 1980. Método gráfico e estimativa de índice alimentar aplicado no estudo de alimentação de peixes. Boletim do Instituto Oceonográfico, 29:205-207.

Occhi RN \& Oliveros OB, 1974. Estudio anátomo-histológico de la cavidad bucofaringea de Leporinus obtusidens Valenciennes y su relación com el régimen alimentario (Pisces, Tetragonopteridae). Physis, 33:77-90.

Okada EK, 2001. Gradientes espaço-temporais na pesca artesanal do reservatório de Itaipu. [Tese]. Maringá: Universidade Estadual de Maringá.

Okada EK, Agostinho AA \& Gomes LC, 2005. Spatial and temporal gradients in artisanal fisheries: a case study of the Itaipu Reservoir, Brazil. Canadian Journal of Fisheries and Aquatic Sciences, 62:714-724.

Pimentel D et al., 2000. Environmental and economic costs of nonindigenous species in the United States. Bioscience, 50:53-65.

Rodrigues SS, Navarro RD \& Menin E, 2006. Adaptações anatômicas da cavidade bucofaringiana de Leporinus macrocephalus Garavello \& Britiski, 1988 (Pisces, Characiformes, Anostomidae) em relação ao hábito alimentar. Biotemas, 19:51-58.

Rosecchi L \& Nouaze Y, 1987. Comparaison de cinq indices alimentaries utilisés dans l' analyse des contenus stomacaux. Revuedes Travaux de I'Institute de Peches Maritimes, 49:111-123.

Suriani AL, Franca RS \& Rocha O, 2007. A malacofauna bentônica das represas do médio rio Tietê (São Paulo, Brasil) e uma avaliação ecológica das espécies exóticas invasoras, Melanoides tuberculata (Müller) e Corbicula fluminea (Müller). Revista Brasileira de Zoologia, 24:21-32.

Takeda AM et al., 2002. Limnoperna fortunei dispersion - a new macrobenthic population in the Itaipu Reservoir (Brazil). In: Anais do Symposium on Reservoir Management in Tropical and Sub-tropical Regions. Foz do Iguaçu, PR, Brazil. p. 1-7.

Takeda AM, Fujita DS \& Fontes Jr. HM, 2004. Perspectives on exotic bivalves proliferation in the Upper Paraná River floodplain. In: Agostinho AA et al. (Ed.). Structure and functioning of the Paraná River and its floodplain. Maringá: EDUEM. p.97-100.

Takeda AM, Fujita DS \& Fontes Jr HM, 2007. Bivalves invasores no rio Paraná. In: Tópicos de Malacologia- Ecos do XVIII EBRAM. Sociedade Brasileira de Malacologia. p. 81-86.

Vitule JRS, Freire CA \& Simberloff D, 2009. Introduction of non-native freshwater fish can certainly be bad. Fish and Fisheries, 10:98-108.

Vitousek PM et al., 1997. Human domination of Earth's ecosystems. Science, 277:494-499.

Received: June 2010 First Decision: July 2010 Accepted: August 2010 